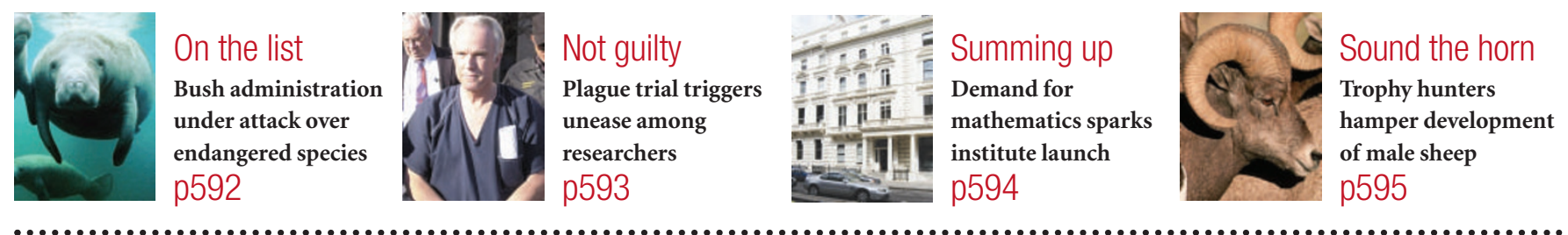

\title{
Berkeley accused of biotech bias as ecologist is denied tenure
}

Rex Dalton, San Francisco

An ecologist at the University of California, Berkeley, best known for his outspoken criticism of genetically modified crops and of the university's links with the biotech industry, has been denied tenure. But some of his colleagues are now questioning the integrity of the decisionmaking process.

The Berkeley campus has been wracked by dissent ever since it signed a lucrative deal in 1998 with the Swiss-based firm Novartis, giving the company privileged access to the university's plant scientists. Ignacio Chapela was prominent among a group of vocal protesters against the deal. Subsequently, he became embroiled in controversy after publishing disputed research suggesting that transgenes flowed from modified crops into natural maize in his native Mexico.

Chapela's supporters now charge that his denial of tenure calls into question the prestigious university's willingness to back academics who challenge powerful agricultural industrial interests. But university administrators argue that Chapela's publishing record in the seven years since he arrived at Berkeley is too weak to justify tenure.

One Berkeley scientist involved in the tenure review was so upset at the handling of the case that he has broken the strict confidentiality of the process to complain. Population biologist Wayne Getz, who sat on an ad hoc faculty committee that recommended giving Chapela tenure, says that the ecologist received overwhelming faculty support, but alleges that the review then was "hijacked" by Chapela's opponents in the university.

"The process was so irregular; it is illegitimate," asserts Chapela, who received notice on 26 November from Berkeley's chancellor Robert Berdahl that his academic contract will expire next June. University officials won't comment on the specifics of Chapela's case, but a spokesman says: "We stand by our tenure process; it is the most strenuous in the country."

Documents from the chancellor's office raise a number of concerns about Chapela's performance, including the disputed maize article and his research publications. "The overall assessment of reviewers was that Chapela's good record of teaching and excellent service stood in sharp contrast to a disappointingly modest publication record," says the document rejecting tenure.

Chapela works for the university's Department of Environmental Science, Policy, and Management. Shortly after arriving at Berkeley, he became embroiled in the row over the deal with Novartis - now known as Syngenta. Then, in 2001, Chapela and a student published a paper in Nature reporting that transgenes had flowed into native maize in the southern Mexican state of Oaxaca, fragmenting and integrating across the genome (D. Quist and I. H. Chapela Nature 414, 541-543; 2001). The article stirred international debate and, after additional review, Natureissued a statement saying that it would not have been published had certain techni$\mathrm{cal}$ issues been uncovered during the paper's initial review. Chapela and his student acknowledged some flaws, but stood by their main findings (D. Quist and I. H. Chapela Nature 416, 602; 2002).
Chapela's tenure at Berkeley has been under review since November 2000. As part of the process, in his department, 32 faculty members voted for tenure and one against, with three abstentions. And in summer 2002, an ad hoc committee of five colleagues familiar with Chapela's field voted unanimously in favour of tenure.

But the review then took an unusual course. The chair of the ad hoc committee was quizzed by the university hierarchy about his committee's report and its membership; questions were raised about whether two members
The chair, whose identity has were biased. The chair, whose identity has
not been revealed, then resigned in the autumn of 2002, disavowing his committee's report. But committee members weren't told that this had occurred.

Getz, a tenured professor in Chapela's department, only learned of what happened to the report of the committee he had served on in June this year. He immediately wrote to the chancellor's office: "I am concerned that the process of tenure evaluation, that works so well in almost all cases, has somehow been tainted or corrupted by those on our campus who belong to the camp that believes Chapela should not be tenured."

Another faculty member involved in the review says: "The process clearly failed when the chairman resigned. This sort of case sends a chill through the community of researchers."

A university spokesman claims that the ad hoc committee's chair resigned after realizing that his committee didn't have the required expertise to analyse Chapela's research, and argues that these actions were compatible with Berkeley's normal tenure-review process.

Chapela and other faculty members were this week planning to hold a meeting on academic freedom at the Berkeley campus. His tenure battle is likely to take centre stage. "I just can't walk away," Chapela says. "I have to fight." 